\title{
FUNDAMENTAL FOUNDATIONS OF LOGISTICS PHILOSOPHY
}

\section{Borinshtein Ye. R.}

\section{INTRODUCTION}

Development of the world of global space at the present stage is characterized by intensive integration processes. These processes appear not only on a global scale, but also on personal, intergroup levels. Of great importance are the social connections of a person and the possibilities of an individual and society related to building up these connections. Only a creatively developed personality, aimed at self-realization, can effectively develop social ties, thereby contributing to the evolution of a personality with standard priorities into a creative personality. And an invaluable partner in this process seems to us a logistics philosophy.

In ancient Greece, logistics was understood as the art of performing calculations. Logisticians were called special state controllers. According to the records of Archimedes, in the V century $\mathrm{BC}$, during the highest prosperity and power of Athens, in all of ancient Greece, there were 10 logisticians.

In ancient Rome, logistics was already understood as distribution of products. Byzantine, I introduced the term "military specifics" into understanding, meaning "rear, supply of troops" under it. Later on, in the XVII - XVIII centuries, the term "logistics" had somewhat different interpretation. So, the German philosopher Gottfried Wilhelm Leibniz called mathematical logic logistics. For mathematical logic, this term was officially fixed at a philosophical conference in Geneva in 1904. In Ukraine, the term "logistics" began to be used recently in the context of its understanding as a science and" about planning, organizing, managing and regulating the movement of material and information 
flows in space and time from their primary source to the final consumer",

In general, it should be noted that for a long time "logistics" was considered an applied military discipline, and only relatively recently it began to be associated with economic processes, or such important ones as the management of commodity, financial and information flows. The first who began to consider logistics as the most important part of the business were American Scientists P. Converse and P. Drucker. They saw great potential in it, defining them as "the last frontier of economy" or as "the unidentified mainland of the economy". In 1955, in America the first publications appeared, which were set out the theoretical basis of logistics and possibilities of its use in the economy.

In 1974, the international community for the supply of engineers has identified logistics as the art and science of management, engineering, and technological activities aimed at fulfilling the requirements of planning, providing and maintaining support to the goals, plans and operations.

Modern scientific knowledge has greatly expanded the interpretation of logistics, implying a conceptual understanding of the term in different dimensions. But it seems to me that only the philosophical dimension can show the multidirectional nature of the use of logistics in a modern transforming society. And one of the important areas of logistics is the systemic activity of a person aimed at developing his creative potential, self-realization.

\section{Philosophy of logistics as a scientific discipline}

Logistics is understood by me as an interdisciplinary research field directly related to the search for new opportunities to improve the efficiency of the different systems of human activity.

1 Бакаєв О. О. Теоретичні засади логістики. К.: Київський університет економіки і технології транспорту. 2003. Т. 1. 430 с. 
When building logistics, a systematic approach finds expression in combining various processes of human sociocultural activity. At the same time, it should be understood that the main priority of logistics is the priority of the consumer. In the implementation of the principles of logistics, huge potential opportunities are hidden to increase the efficiency of the individual, social group, and society as a whole.

The purpose of logistics as a system is revealed in the essence of its benefits to society. And the utility of logistics is determined by those losses that occur when something necessary is absent in the right place at the right time. This implies the priority importance of planning, but often it is forgotten about the priority importance of systematicity. The logistics philosophy provides an opportunity to combine these priorities into a single whole.

The logistics philosophy is doomed to develop theoretical algorithms of human activity aimed at optimizing the costs of sociocultural and material resources of society, which, contrary to prevailing stereotypes, are not unlimited. So it is important to develop a system of replenishment of these resources.

Replenishment of sociocultural resources directly depends on the system of recreation existing in society. With material resources, the situation is different. The economic component based on high-quality marketing is paramount here.

Therefore, the philosophy of logistics should focus on the management system of socio-cultural and material resources. The creation of such a system, its effectiveness, depends on how much the individual will be oriented and able to engage in creative activity, since only a creative approach allows one to better overcome the challenges of modern society.

Consequently, the philosophy of logistics is the science of systemic management of human activities, sociocultural and material resources of society, based on the priorities of a creative person. 
Hence the main goal of the philosophy of logistics is the formation of a methodology for managing human activities, focused on the development of a creative person.

The tasks of the philosophy of logistics are:

- determination of the theoretical concept of developing the foundations for the efficient use of logistics in various human activities;

- characteristics of the structure of the philosophy of logistics;

- development of a logistic system for the functioning of modern society, focusing on the priorities of the creative person;

- the study of logistics technologies for managing socio-cultural and material resources;

- analysis of the information specifics of existing logistics systems;

- Consideration of the systemic virtualization of modern society in the context of creating a logistics system for its management;

- Organization of logistic management of the company.

For the scientific study of the philosophy of logistics, it is necessary to formulate conceptual approaches, a conceptual framework, the principles of building logistics systems. Only then can we speak with confidence about the significance of this science. Indeed, according to the definition of Immanuel Kant, science is called "all doctrine, if it is a system, that is, a certain set of knowledge, ordered according to principles"2. Based on the stated methodological premise, the scientific direction "philosophy of logistics", in order to become a science that meets all the prerequisites of scientific knowledge, it is necessary to transform into internally streamlined scientific system.

Accordingly, it is necessary to develop a system of laws, categories and principles that explain the nature of the systemic management of

${ }^{2}$ Кант И. Изречения [сост. и науч. ред. В. Н. Брюшинкин]. Калининград: Изд-во РГУ им. И. Канта. 2010.91 с., р. 34. 
human activities, sociocultural and material resources of society. Organically, at the generalization level, laws and categories of philosophy, logic, logistics, sociology, and a number of other humanitarian disciplines are included. That is, a certain complex is being created, the priority of which is the development of a creative personality.

The logistics philosophy as a young and dynamic science today is rapidly moving through its formation, with the practical part often ahead of the theoretical one. A paradoxical situation is created when the theory has not yet been fully developed, and the practical application is already fully functioning, dictating its own norms and rules.

Therefore, in the philosophy of logistics, today many concepts and categories are not specified, and often even absent. And the causal relationships identified and already studied do not have such a level of scientific generalization that would allow them to be attributed to new laws, which complicates the assimilation of theoretical material already accumulated by science. Unfortunately, the shortage of specific theoretical content limits the possibility of developing a scientific theory of logistics philosophy. This is due not only to the fact that science is in its infancy, but also to the fact that initially there is no clear understanding of its significance, the central idea.

Let us hope that this work will fill in the indicated "white spots".

First of all, it seems important to understand the need for a systems approach in the philosophy of logistics as a scientific discipline.

When solving logistic problems from the perspective of a systematic approach, it is necessary to single out the methodological part, in which the system principles that determine the specific way of studying reality are concentrated, in other words, systematicity clearly appears here as a methodological substantiation of the logistic type of research.

The systematic approach is a general scientific methodology and develops under the influence of certain needs of scientific thinking in general. The methodological effectiveness of a systematic approach in 
logistics is measured by how capable it is to play a constructive role in the mood and development of logistic research subjects, that is, its ability to systematically develop various types of activities. Therefore, in the philosophy of logistics and, today, many concepts and categories are not specified, and often even absent. And the causal relationships identified and already studied do not have such a level of scientific generalization that would allow them to be attributed to new laws, which complicates the assimilation of theoretical material already accumulated by science. Unfortunately, the shortage of specific theoretical content limits the possibility of developing a scientific theory of logistics philosophy. This is explained not only by the fact that science is in its infancy, but also by the fact that initially there is no clear understanding of its significance, central idea.

Let us hope that this work will fill in the indicated "white spots".

First of all, it seems important to understand the need for a systems approach in the philosophy of logistics as a scientific discipline.

When solving logistic problems from the position of a systematic approach, it is necessary to single out the methodological part, in which the system principles that determine the specific way of studying reality are concentrated, in other words, systematicity clearly appears here as a methodological substantiation of the logistic type of research.

The systematic approach is a general scientific methodology and develops under the influence of certain needs of scientific thinking in general. The methodological effectiveness of a systematic approach in logistics is measured by how capable it is to play a constructive role in the mood and development of logistic research subjects, that is, its ability to systematically develop various types of activities.

Therefore, a systematic approach to the philosophy of logistics is aimed at developing specific cognitive tools that meet the challenges of research and construction (synthesis) of complex logistics systems. It represents the foundation of the totality of modern logistics research. 
A systematic approach allows you to "open the door" of the basis of various phenomena and processes in our lives. So, we can talk about the paradigms of the philosophy of logistics.

The paradigms of the philosophy of logistics are closely related to the development of society. These include: sociocultural; economic; analytical; informational; marketing; existential and integral.

Around these, it seems to me, fundamental paradigms in various countries today, various scientific schools, research groups, and philosophical and logistic communities have concentrated.

Summarizing the ideas of a number of researchers, as well as based on the philosophical certainty of the sociocultural paradigm, the following components can be formulated:

- consideration of the philosophy of logistics as a system of global scientific knowledge, included in the world-historical process;

- understanding of the philosophical and logistic system in its conditioning by anthropogeographic diversity and intercultural interactions;

- identification of sociocultural constants, variables and laws governing the development of society in the context of a common coordinate system based on the needs of modern man;

- artistic and aesthetic identification of the unique forms of the spatio-temporal organization of global sociocultural processes related to the development of a creative personality.

Thus, we can say that because of its philosophical status, the sociocultural paradigm is realized not so much in the description of the private interconnections of individual elements of society and culture, but in the panoramic display of the phenomena studied in the context of global sociocultural diversity, while providing a general vision of the situation.

The heuristic possibilities of the sociocultural paradigm should be highlighted, forming an intellectual personality capable of creatively 
fulfilling the tasks it faces, as well as effectively modernizing these tasks in accordance with their vision of the situation.

The economic paradigm is one of the most studied in the context of the traditionally established point of view on the study of the logistics system as an economic system, "with high adaptive properties in the process of performing a set of logistic functions and operations". ${ }^{3}$ For the philosophy of logistics, borrowing the conceptual apparatus and a number of semantic units and actions of logistics from the point of view of its economic components will certainly be valuable. So, the problem of optimizing the management of stream processes can be transformed into the problem of optimizing the management of various processes taking place in society based on the interaction of the internal environment with the external (personality, social and cultural groups with the society), maximizing profit (developing a creative person who simultaneously possesses skills and the skills to adapt as much as possible to the ongoing transformations and even cause them in line with social progress) and the like. Great importance in the economic paradigm is attached to human potential as a key factor in the scientific and technological revolution.

The main quality of the economic specifics of logistics is "ensuring the supply of the necessary products to the right place, at the specified time, at the optimal cost of the required quantity and quality" 4 Here, significant is not only an understanding of space and time, but also an understanding of the timeliness of various kinds of actions in different periods of time, that is, what is useful today no longer seems necessary tomorrow. Accordingly, the chain of categories "yesterdaytoday-tomorrow" acquires a completely different semantic meaning.

\footnotetext{
${ }^{3}$ Логистика: учеб. Пособие [под общ. ред. М. А. Чернышева]. Р.н/Д: Феникс. 2009. - 459 с., р. 25.

4 Логистика: учеб. Пособие [под общ. ред. М. А. Чернышева]. Р.н/Д: Феникс. 2009. - 459 с., р. 49.
} 
The economic paradigm of the philosophy of logistics without fail insists on compliance with the norms, traditions, customs, and value system that have developed in society. It helps to comprehend the fundamental changes in the economic life of society, consisting in ideas about the sources and forms of wealth, the goals of economic activity, and the mechanism for managing the economy. If mercantilism identified the wealth of the nation with money, and its source - with the sphere of circulation, which is fully justified for the XVI - XVII centuries, when foreign trade was crucial for the formation and development of national markets, today intellectual property and the ability to produce it are the main wealth reproduce. This requires a combination of the interests of man, society and the state.

The economic paradigm is precisely what should ensure: building up social wealth in the spiritual sphere; social character of public relations; orientation of economic relations to qualitative growth; Achievements of scientific and technological progress, advancing the development of mental labor and increasing its role in the development of the nation; a radical change in thinking, education, and upbringing, based on universal and specific national values; correlation of state and market regulation in a mixed economy; enhancing the role and interests of man in a civilized process.

The analytical paradigm represents the initial classical approach to logistics as a theoretical science dealing with the problems of managing material flows in production and circulation. An example of the concentration of research around the analytical paradigm is American universities, where logistics and philosophy are fundamental disciplines. The analytical paradigm is based on the traditional theoretical base, using traditional universal philosophical methods for research, understanding the forms and contents of social development, studying the relationship "man-world" in the logistic chain of interaction of the main forms of human activity 
"civilization-culture-humanity", analysis of spiritual life society, man, the spiritual world of the individual. A characteristic feature of the application of the analytical paradigm is the construction of a rather complex various kinds of models that reflect the specifics of the problem being solved. Such models require a large amount of initial information and the development of complex decision-making algorithms in logistics management, and their practical application with a correctly specified coordinate system gives the maximum effect.

The information paradigm appeared in the 1960s and is closely related to the rapid development of information and computer technologies. The philosophy of this paradigm is that, on the one hand, it is possible to formulate the general problem of managing the material flow of a logistic facility, and on the other, to obtain information and computer support for solving the problem.

The theoretical basis of the information paradigm is a systematic approach, which is used both for modeling the logistics facilities themselves and for the synthesis of information and computer support systems. The main logistics management strategies are to automate the simplest operations and use information and computer support to solve more complex logistics problems.

From the beginning of the 1980s to the present, in a number of developed countries, a marketing paradigm is often used in the synthesis of logistics systems. Models using this paradigm have the goal of describing and explaining the relationship between the logistics system and the firm's ability to compete.

The synthesized logistics system should realize the strategic goal of the enterprise and its participants-the development of a comprehensive concept of competition in the market for finished products, which requires the solution of such marketing problems as market research, determining the position of the company in the market, forecasting demand for products. The scientific basis of this paradigm is 
mainly socio-humanitarian and economic disciplines, as well as disciplines located at the junction between them (philosophy, sociology, history, cultural studies, economics, management, management of sociocultural activities, personnel management, marketing and others). An example of the use of the marketing paradigm abroad is the LRP system (Logistics Requirements Planning) - a system for controlling input, internal and output material flows at the firm level, territorial production associations and macro-logistic structures. The system is also known as the "Supply Chain Management System". Interestingly, this kind of system can be applied in the educational activities of higher education. So, we find out the characteristics of students who entered the first year of a particular educational institution, their characteristics at its graduation, the characteristics of teachers, and calculate the quality of this university.

In studying the direction of the philosophy of logistics, one should not forget about the existential paradigm. Today, man insists on the importance of his autonomous space, continuing the line of freedom as a natural state of his being. The meaningfulness of human existence, the problem of freedom, the problem of love, the significance of everyday life - these and similar problems have risen to a person totally. Today, mankind is devoting enormous resources and making tremendous efforts to solve these problems. Today they are more important than ever for the world community and for Ukraine.

The value of morality in the modern world is difficult to overestimate. Because without the existence of morality today, the existence of humanity is impossible. So, each Wehrmacht officer carried in his bag two books by Friedrich Nietzsche - "The will to power" and "So said Zarathustra". They felt Übermensch, supermen. But it turned out that the ideology of the Superman is absurd in essence. She is absurd beyond the highest morality. And millions and millions of people were killed absolutely pointless. The very presence of concentration camps is an absurd destruction of human potentiality. Just like in the Soviet 
Union. Superhumans, former revolutionaries, true rulers of the world, without morality turned out to be monsters. That is why today, when Ukraine is at war with an external aggressor, more than ever, there is a need to return the ideals of morality and humanism to the humanities. At this time, unfortunately, in the field of higher education in Ukraine there is a reduction in humanitarian disciplines, which is not only logically incorrect, but also reduces the possibility of developing a creative person.

Today, many organizations in practice, as a rule, try to use all the above paradigms at the same time. However, in recent years, a new logistic paradigm, which most researchers call the integral, has taken root and is widely spread. It takes into account the following prerequisites for the development of society:

- understanding of the mechanisms of the philosophy of logistics as a strategic element in competitive opportunities;

- new prospects for integration between logistics partners, new organizational relations;

- radically changed information capabilities, in particular information and computer technologies, making it possible to universalize control and management in various spheres of society;

- the transformation of the system of meaning-life orientations based on self-realization and personal freedom.

These paradigms serve to understand the strategy of the philosophy of logistics as a scientific discipline aimed at developing conceptual systemic solutions for a person, society, and the state. At the same time, decisions can be: a strategic plan, when a general direction of activity is developed for the long term; tactical plan, in which we are talking about the medium term of activity, requiring a detailed understanding of the modern development of mankind; operational plan, consisting in the short-term moment of decision-making today, here and now, and requiring accurate knowledge of the individual's capabilities. 
But the logistics philosophy is good in that it shows how to most effectively combine these solutions. From my point of view, this option for the development of the situation is clearly manifested in the ideologies of the philosophy of logistics.

The term "ideology" is actively used in philosophy, sociology, history, political science, cultural studies, linguistics and other humanities. At the same time, a clear definition of the term "ideologem" has not been developed. Therefore, in the context of this work, I understand the ideology as a specific integral unit of controlling the mass consciousness of mankind, society as a whole, based on the ideas (or ideals, as you like best) of sociocultural activity and rallying society around the category of public good.

From here we can distinguish the following ideologies of the philosophy of logistics:

- creation of logistic life systems;

- optimization of marketing communications in modern society;

- development of human development and socialization technologies;

- ensuring optimal information and computer life;

- the creation of a system of maximum favored development of the creative potential of the individual;

- management of financial resources of the state in terms of priorities for self-realization.

\section{He role of logistics philosophy in thedevelopment of creative personality}

Each of us is endowed with the ability to solve problems, however, people using a creative approach to solving problems have certain character traits. Firstly, they absorb the experience of others, like a sponge. They have an enormous personal reserve: the things that they read, saw, or heard; places where they have been or have worked; and the people they know. 
Studies have shown that creative people strive for independence, self-sufficiency, self-discipline, perseverance, selfaffirmation, and to a large extent tolerant of uncertainty. They take risks and have a powerful ego. In other words, they are guided by an internal impulse. They do not care about standards and opinions; they are little interested in interpersonal relationships. Creative people usually have innate skepticism and a very sharp mind. They are active, observant and executive; they draw conclusions with the help of intuition rather than logic. They have the ease that allows them to find new associations.

Therefore, today the development and formation of a creative personality seems to me paramount.

Creativity is an activity that leads to the creation of new unique material and spiritual values. The uniqueness of creative activity lies in the fact that a person displays his personality in it. The opinion was established that people who are capable of creative activity are called creative personalities. Which, from my point of view, is wrong. Potentially, all people are creative. It is only important to be able to develop a creative principle in a person.

A creative person is a person who creates fundamentally new products as a result of his activities. In the context of the foregoing, the direction of the logistics philosophy lies not only in the creative development strategy of the individual, but also in the suggestion of the possibility of self-realization of the personality, its creative efforts. Therefore, the logistics of a creative person is knowledge aimed at developing the creative potential of a person and providing integrated coordination of managing the creative resources of a society.

\section{The prospects of modern man due to the logistics of a creative} person are immeasurably higher than those of previous generations, which is why I consider the main task of modern education to pave the way to HOMO GENIALIS. What should be the basis of the focus of education on HOMO GENIALIS? 
1. The speed of solving the problem allows not only to reduce time, but also to find the right way more efficiently. Do not be afraid to make a mistake, no one will kill for a mistake, and if you find the right solution, you will receive a well-deserved reward.

2. A great opportunity to express brilliant qualities in a world of maximum freedom. What qualities? Intelligence, gift, ability, culture, fantasy.

3. Planning.

4. Technique for solving problems.

5. The desire to defend one's opinion (previous generations also had the ability).

6. Tolerance.

The prospects of modern man are the infinity of world space. Try to dream and develop this theme. The development of a creative personality allows you to create a huge number of combinations of problem solving and choose from them the most useful for humanity.

The creative personality, at its maximum development, is embodied in inventions that benefit Humanity, thanks to which society evaluates it (the personality is E. R.) as a genius.

The concept of "genius" comes from the Latin term "genius""genius". Genius is understood as "the highest degree of creative giftedness, which manifests itself as an original ability of understanding (intuition), combination of various elements (fantasy), creative formation and image, as well as a person possessing this giftedness", . In genius, society emphasizes the superpowers of the individual. Genius is a freely used term used to emphasize the level of intellectual or creative development of an individual. A person with superpowers of this type is called a genius. But, if "genius" is a purely individual and unique alloy of birth and upbringing, then "genius" is already a social phenomenon, which is greatly influenced by the social environment. In my opinion,

\footnotetext{
${ }^{5}$ Галактический колледж URL: http//www.galactic.org.ua>clovo/p-g7.htm.
} 
when analyzing genius, it is necessary to take into account the great importance not only of the social, but also of the cultural environment, their mutual influence on the development of this phenomenon in each individual person.

It is well known that genius is, first of all, an individual feature of a specific personality. People of genius are considered to be those who have natural, cultural and social foundations and, no less important, who did something unusual that brought spiritual or material super-benefits to society. Moreover, this unusual is almost impossible to repeat.

It seems to me that genius can fully manifest itself only in a creatively developed personality. Moreover, it is vital for society to strive for manifestations of genius in an environment of their own kind, since only in this case the maximum development of a creative personality with its positive characteristics for society is possible.

Based on the foregoing, I would single out the following characteristics of a creative person:

1. Speed - the ability to express the maximum number of ideas (in this case, it is not their quality that matters, but their quantity).

2. Originality - the ability to generate new non-standard ideas (this can manifest itself in answers, decisions that do not coincide with generally accepted ones).

3. Completeness - the ability to improve your "product" or give it a finished look.

4. The ability to see the problem where others do not see it.

5. The ability to minimize mental operations, replacing several concepts with one and using symbols that are increasingly capacious in informational terms.

6. The ability to apply the skills acquired in solving one problem to solving another.

7. The ability to perceive reality in its entirety, without splitting it into parts.

8. The ability to easily associate distant concepts. 
9. The ability of memory to provide the right information at the right moment.

10.The flexibility of thinking.

11.The ability to choose one of the alternatives for solving the problem before checking it.

12.The ability to incorporate newly acquired information into existing knowledge systems.

At the same time, in modern conditions, much attention is paid to the creative personality. It is a creative person who becomes especially demanded by society, since the transformations that have taken place in sociocultural, socioeconomic, and sociopsychological life in recent decades require a person to have qualities that allow him to be innovative in approaching and responding adequately to any life changes. Confidence in their decision, despite the difficulties that arise, the ability to take responsibility for a non-standard position, opinions that contribute to solving the problem are the necessary qualities that a future specialist should be able to compete in a rapidly changing world. The uniqueness of each person is not in doubt, however, to prove themselves, express their exclusivity is a problem for most people. Creativity of a person allows not only to effectively realize a person's life potential, but also to find his place in life.

The category "creativity" in the current sociocultural situation is presented as the embodiment of creative human thought in traditional areas of life, but in unconventional ways and in an unusual form. The secret of a creative way of thinking lies in the very methodology of creating values, which, being inherently innovative, is beyond the boundaries of existing technologies, generally accepted norms and rules. Note that modern scientists emphasize the difference between the result of solving a problem in a creative way and creative actions that determine the methodology for solving a problem. From their point of view, the result of a creative approach is understandable, traditional, evaluated easily and quickly. And the way to achieve this 
result is unconventional, and it is precisely in this that its effectiveness lies ${ }^{6}$.

But, it should be emphasized not psychological, but sociophilosophical, existential foundations of creativity and a creative personality, providing opportunities to develop a development strategy for Homo Genialis.

I would emphasize that creativity is Man's ability to create something innovatively new or solve a problem in an innovative new way, based on: his high intellectual abilities, intuition of his talent, paradox of thinking; willingness to produce fundamentally new ideas; divergence of the principle of cognition of the world.

Hence, a creative person is a person with the ability to create fundamentally new forms of cognition and problem solving through mastering teaching technologies, distinguished by innovative methods of creating innovative ideas in demand, able to realize an idea that does not have a standardized solution methodology, striving for divergent knowledge of the noosphere.

Signs of a creative personality: a constant need for freedom, intelligence, activity, creativity, aesthetics, inspiration; the desire for constant knowledge (the cognizing subject-according to I. Kant), focus on innovation, research of new things, the possibility of an original vision of the situation, the ability to positive synectics (combining heterogeneous elements for a more successful solution to an intractable problem).

Only a creative person who uses the logistic apparatus to solve a problem, only a person who can create precedents in cognition can change the world!

6 Шишова Н. В. Креативные технологии в рекламе и связях с общественностью: монография. Ростов н/Д.: Издательский центр ДГТУ. 2010. 128 c., p. 5. 
It is important, given the epistemological essence of man and the systemic nature of philosophical knowledge, to take into account the fundamental foundations of the existence of Man and Mankind. It is an activity without which there is no Homo sapiens as a species.

World transformational-globalization processes are forcing society to direct its efforts to the formation of logistics systems in various areas of life. Especially important in this case is the development of a creative, system-minded person who could not only engage in innovations, but also offer a concept for the development of his knowhow. This approach allows you to ultimately maximize profits and minimize the costs of any innovative proposal. Therefore, today the personality's ability to logistic thinking is more than relevant, and, as a result, an indicator of society's creativity, variations in creating conditions for attracting investment in all spheres of life in order to achieve a level of development that is adequate not only to the $21 \mathrm{st}$ century, but also to post-post-post- (and so on) the modernization revolution of consciousness. And most quickly it is displayed in sociocultural activities.

The understanding of sociocultural activity in its modern meaning began, in my opinion, with the analysis of the Soviet scientist M. S. Kagan, who, considering human activity "as a two-level biosocial system, emerging as a result of transformation, both in phylogenesis and ontogenesis of the life of living beings, into the sociocultural activity of man as a social being, "he believed that the first level of this system is the biological activity of man, and the second, higher, specifically human valid activity (sociocultural): “... A person's biological activity remains the material base on which the building of sociocultural activity is built, but this latter incorporates its own biological foundation, preventing it from functioning in its pure form"7. Although the first

${ }^{7}$ 6. Каган М. С. Человеческая деятельность (Опыт системного анализа). М.: Политиздат. 1974. - 328 с., р. 44. 
studies of the category of "socio-cultural activity" (today we are already formulating this concept as "sociocultural activity," thereby emphasizing the inextricable unity and interaction of the world of society and culture) began in the fifties of the 20th century. So, Joffre Roger Dumazedier defined it as "conscious, deliberate, organized, even planned acculturation, opposing the methods of blind and anarchic socio-cultural conditioning" ${ }^{\prime}$. Scientists and government agencies assumed that the main purpose of socio-cultural activities is to create conditions for familiarizing people with culture, adapting to scientific and technological changes. However, transformational processes in society, globalization, and postmodernization of consciousness have changed the very understanding of the essence of the process.

Today, sociocultural activity means: 1) activities aimed at creating the most favorable conditions for development, self-affirmation, selfrealization, being an individual and a social group, a collective in the field of free time and leisure; 2) activities focused on the preservation and transfer of cultural values, as well as on the development, selfassertion and self-realization of individuals and groups through their familiarization with cultural values; 3) the process carried out in the educational sphere, all of whose components are filled with human meanings and serve as the maximum manifestation of the individual's creative abilities, the creation of a creatively thinking personality, directing its activities to self-expression in the world of culture.

In these definitions, I have expressed three areas of study of sociocultural activity, but there may be more. Today, sociocultural activity is a social institution of society, along with culture, education, family and other institutions. He defines our life, since rarely when we are outside his sphere.

${ }^{8}$ Туев В. В. Социально-культурная деятельность как понятие (включение в дискуссию) // Вестник Московского университета культуры и искусства. 2006. Вып. 23. С. 25-39, p. 30. 
That is why logistics becomes a critical part of sociocultural activity as a system-conceptual view of the world. By logistics I mean an interdisciplinary scientific field that is directly related to the search for new opportunities to increase the effectiveness of various systems of human activity. The logistic approach in modern society leads to interfunctional, interorganizational coordination and management of integrated logistics flows, allows you to transform not only the life of a particular person, but also those around him, and, in the final version, the whole society as a whole. Information obtained as a result of logistics activities is of particular importance in the formation of modern logistics systems. A specialist with such abilities is valued more than "worth its weight in gold". Hence, for a modern person, the possession of logistics operations is extremely important.

As a result, it became necessary to develop the logistics of a creative person, which I decipher as knowledge aimed at developing the creative potential of a person and providing integrated coordination of managing the creative resources of a society.

It is precisely sociocultural activity that can develop and transform the creative resources of society in the optimal order, implying a sociocultural approach to the educational process, as a unity of culture and society, transformed by human activity, his constant desire to transform, rebuild the world for himself. The sociocultural approach to the conditions of existence, life activity integrates the transformation of human life: the relationship of man and society, the nature of culture, the type of sociality. Therefore, it is the logistics of sociocultural activity that helps to solve many sociocultural problems with their specific means, forms, methods, which tend to become universal.

Based on the foregoing, by the logistics of sociocultural activities I understand the conceptual system aimed at creating new opportunities to increase the effectiveness of various areas of human activity, as well as the creation of such systems with the help of which processes of inculturation, socialization, and mutual sociocultural 
adaptation will take place in modern and future society, develop a creative personality.

\section{CONCLUSIONS}

Modern scientific knowledge needs a systematic understanding of the processes taking place in society, the problems of HUMAN and HUMANITY, and the dialectical approach to reality. That is why the introduction of the scientific discipline of the philosophy of logistics seems to me significant. The most important entity, relatively speaking the "end result" of the philosophy of logistics, is the systemic activity of a person aimed at developing his creative potential, self-realization, and the formation of a creative personality.

Logistics is understood as an interdisciplinary scientific field directly related to the search for new opportunities to improve the efficiency of various systems of human activity.

The logistics philosophy, based on its essence and objectives, should be guided by the socio-cultural and material resources management system. The creation of such a system, its effectiveness, depends on how much a person is able to engage in creative activity, since only a creative approach allows one to better overcome the challenges of modern society.

Therefore, the fundamental foundations of the philosophy of logistics as a scientific discipline appear to me in the context of systemic management of human activities, sociocultural and material resources of society, based on the priorities of the creative person.

Of particular importance in the philosophy of logistics is a systems approach that helps to understand the essential foundations of various phenomena and processes in our lives. From here we can talk about the paradigms of the philosophy of logistics.

The paradigms of the philosophy of logistics are closely related to the development of society. These include: sociocultural; economic; analytical; informational; marketing; existential and integral. 
The priority of a creative person in the philosophy of logistics allows a person to experience the pleasure of self-realization manifested in activity. Therefore, a creative person is a person who creates fundamentally new products as a result of his activities. And the orientation of the philosophy of logistics lies not only in the creative development strategy of the individual, but also in the suggestion of the possibility of the self-realization of the personality, its creative efforts.

The desire to find genius manifestations in a creative person leads us to understand the role of a creative person in modern cognitive activity of a person. In view of this, I define a creative person as a person with the ability to create fundamentally new forms of cognition and solve problems by mastering teaching technologies, distinguished by innovative methods of creating innovative ideas in demand, able to realize an idea that does not have a standardized solution methodology, striving for divergent knowledge of the noosphere.

The philosophy of logistics, based on the dialectic of the formation of a creative personality, the development of its creative abilities, evolving thanks to human activity, is a necessary discipline for society and man, based on the ideals of success and prosperity.

\section{SUMMARY}

The paper considers the essence of the philosophy of logistics as an interdisciplinary direction that shapes human activities. The role of logistics philosophy in modern society is studied on the basis of the maximum use of its sociocultural and material resources. The ideological principles of the philosophy of logistics are determined, which are concrete integral units of controlling the mass consciousness of mankind, society as a whole, based on the ideas of sociocultural activity and rallying society around the category of public good. The role of the creative person as the fundamental basis of the philosophy of logistics is substantiated. The focus of the logistics philosophy on the formation of HOMO GENIALIS as the essence of noospheric 
knowledge is analyzed. The significance of a creative person for selfrealization of a person is highlighted. The question is raised about the importance of sociocultural activity in human development. The logistics of socio-cultural activities are considered as one of the most important foundations of the philosophy of logistics.

\section{REFERENCES}

1. Бакаєв О. О. Теоретичні засади логістики. К.: Київський університет економіки і технології транспорту. 2003. Т. 1. - 430 с.

2. Кант И. Изречения [сост. и науч. ред. В. Н. Брюшинкин]. Калининград: Изд-во РГУ им. И. Канта. 2010. - 91 с.

3. Логистика: учеб. Пособие [под общ. ред. М. А. Чернышева]. Р.н/Д: Феникс. 2009. - 459 с.

4. Галактический колледж. URL: http//www.galactic.org.ua/ clovo/p-g7.htm.

5. Шишова Н. В. Креативные технологии в рекламе и связях с общественностью: монография. Ростов н/Д.: Издательский центр ДГТУ. 2010. - 128 с.

6. Каган М. С. Человеческая деятельность (Опыт системного анализа). М.: Политиздат. 1974. - 328 с.

7. Туев В. В. Социально-культурная деятельность как понятие (включение в дискуссию) // Вестник Московского университета культуры и искусства. 2006. Вып. 23. - С. 25-39.

\section{Information about the author:} Borinshtein Ye. R.,

Doctor of Philosophy, Professor, Head of the Department of Philosophy, Sociology, and Management of Sociocultural Activites, South Ukrainian National Pedagogical University named after K. D. Ushynsky 26, Staroportofrankivska str., Odesa, 65020, Ukraine 